\title{
BUILDING COALITIONS: Coalition Facilitator Guide
}

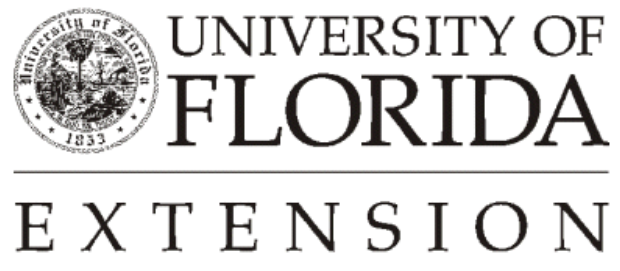

$\mathbf{I}$ stitute of $\mathbf{F}_{\text {ood and }} \mathbf{A}_{\text {gricultural }} \mathbf{S}_{\text {ciences }}$ 
Coalitions and collaborations don't just happen. They come about because of a common problem and goal. But, it still takes a person (or small group of persons) to provide the impetus to bring a group together and start things moving.

This person (or persons) may or may not also assume the role of facilitator.

The facilitator conducts meetings, is able to bring diverse ideas together, also helps the group in working toward mutually identified and achievable goals. Also, the facilitator should be perceived by the coalition participants as trusted and neutral.

\section{Role of the Facilitator}

The most important role of the facilitator is to lay the groundwork for trust to grow as the partnership develops. Openness and informality, the absence of "power plays, and sharing ideas help create on-going relationships. The facilitator builds a foundation of trust and commitment by:

- $\quad$ Teaching people to think in new ways about sharing information and resources.

- $\quad$ Establishing brainstorming sessions to allow all ideas to flow without worrying about methodology.

- Helping tie together various comments, questions and concerns raised in discussion.

- $\quad$ Being sure everyone is aware of decisions being reached.

- $\quad$ Involving the "quiet" people during the meeting.

- $\quad$ Being process and goal oriented. Keeping the meetings and discussion focused on the objective of the group. Being alert and sensitive to the fine line between diversionary and related, helpful discussion.

- Discussing controversial issues thoroughly. Rather than pushing things through, attempt to reach a consensus.

- $\quad$ Being aware of decision-making processes and those used by other coalition members.

\section{Qualities of Facilitators}

If the coalition is to succeed, the facilitator must recognize the usefulness and importance of sharing with others across and within systems. Qualities of a successful facilitator are: 
- A positive mental attitude, especially when people predict failure before the project is given a chance to succeed.

- Strong commitment to the goals of the group.

- Ability to listen and reflect on what was presented.

- Neutrality. If controversial issues arise, he or she needs to ensure everyone in the group has equal opportunity to express their views in an atmosphere of comfort and confidence.

- Awareness of what is not being said and how to have it stated.

- Awareness of when to facilitate and when to participate.

- $\quad$ Ability to "seize the moment." When to conclude the discussion and move to the next step by consensus.

- Good interpersonal communication skills including equal treatment and listening.

\section{Factors Which Inhibit Coalitions}

- Competitiveness.

- Dominating rather than shared leadership that discourages group-decision making.

- Inflexibility in scheduling meetings and activities.

- $\quad$ Lack of understanding about how schools and community agencies operate.

- $\quad$ Hidden agenda for personal advancement.

- Cynicism about the advantage of information sharing.

- $\quad$ Time constraints and pressure to "push things through" without giving adequate time for discussion and to work through conflicts.

- $\quad$ More emphasis on talking than listening.

- $\quad$ Preferring to do things alone rather than spending time negotiating. 
- $\quad$ Prescribing actions for a partnership (coalition) from the top down.

- $\quad$ Lack of procedure for making decisions and solving disagreements when they emerge.

\section{A Tip for the Facilitator}

Keep a journal. It can:

- Track the process of coalition development. It will help analyze, compare and determine overall progress.

- The abilities of the facilitator can determine the success of a coalition group. Walking the tightrope of neutrality, developing trust, and guiding the group toward consensus goals will go a long way toward having a successful coalition. 


\section{References}

Miller, S.M. Coalition Etiquette; Ground Rules for Building Unity, Boston University

Robinson, Estelle R. and Aleta You Mastny. Linking Schools and Community Services: A Practical Guide, Social Policy -Fall of 83, Vol. 14, No.2, Rutgers University, 1989.

\section{Authors}

Charles H. Bell, Associate Professor, District Specialist, 4-H, Ohio Cooperative Extension Service, The Ohio State University.

Penne Smith, County Extension Agent, 4-H, CNRD/Chair, Ohio Cooperative Extension Service, The Ohio State University.

\section{(C)1992 The Ohio State University}

[AFCS Ohio Cooperative Extension Service

This series on Coalition Building was developed by The Ohio Center For Action on Coalition Development for Family and High Risk Youth, Richard Clark, Ph.D., Director. It has been adapted for County Extension Faculty in Florida to facilitate work with local and regional organizations and groups such as non-profits, cooperatives, county extension associations, and others that might benefit from a plan for working together to achieve support for mutual goals.

This document is FY494, Part 2 of the 16 part series adapted for use in Florida by Elizabeth B. Bolton, Professor, Community Development and Lisa Guion, Assistant Professor, Program Planning and Evaluation; Department of Family, Youth and Community Sciences, Florida Cooperative Extension Service, Institute of Food and Agricultural Sciences, University of Florida, Gainesville, 32611-0310.

Reprinted with permission March, 1997. Revised April, 2002.

The Institute of Food and Agricultural Sciences is an equal opportunity/affirmative action employer authorized to provide research, educational information and other services only to individuals and institutions that function without regard to race, color, sex, age, handicap, or national origin. For information on obtaining other extension publications, contact your county Cooperative Extension Service office.

Florida Cooperative Extension Service/Institute of Food and Agricultural Sciences/University of Florida/Christine Taylor Waddill, Dean 